DOI https://doi.org/10.30525/978-9934-26-172-5-29

\title{
РОБОТА АВТОМОБІЛЬНОГО КОЛЕСА З ДОДАТКОВОЮ РУХЛИВОЮ ВАГОЮ
}

\author{
Петров Л. М. \\ кандидат технічних наук, дочент, \\ викладач кафедри автомобільної техніки \\ Військова академія (м. Одеса)
}

\section{Петрик Ю. М.}

стариий викладач кафедри автомобільної техніки

Військова академія (м. Одеса)

\section{Нікішин В. А.}

викладач кафедри автомобільної техніки

Військова академія (м. Одеса)

м. Одеса, Украӥна

По гладкій внутрішній поверхні диска автомобільного колеса 3 верхньої його частини перекочується вага. Автомобільне колесо рухається 3 постійною швидкістю $v_{0}$, рис. 1 , [ 1, 2, с. 1-3].

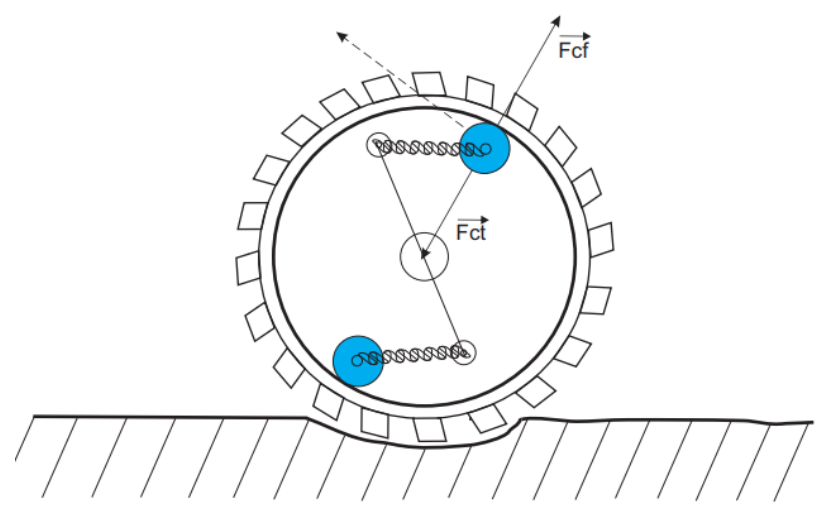

Рис. 1. Автомобільне колесо з додатковою рухливою вагою 
Мета: визначити яку швидкість вага буде мати в зоні плями контакту, тобто, коли вага буде в зоні контакту шини з опорною поверхнею.

Зв’яжемо осі координат з автомобільним колесом, рис. 2.

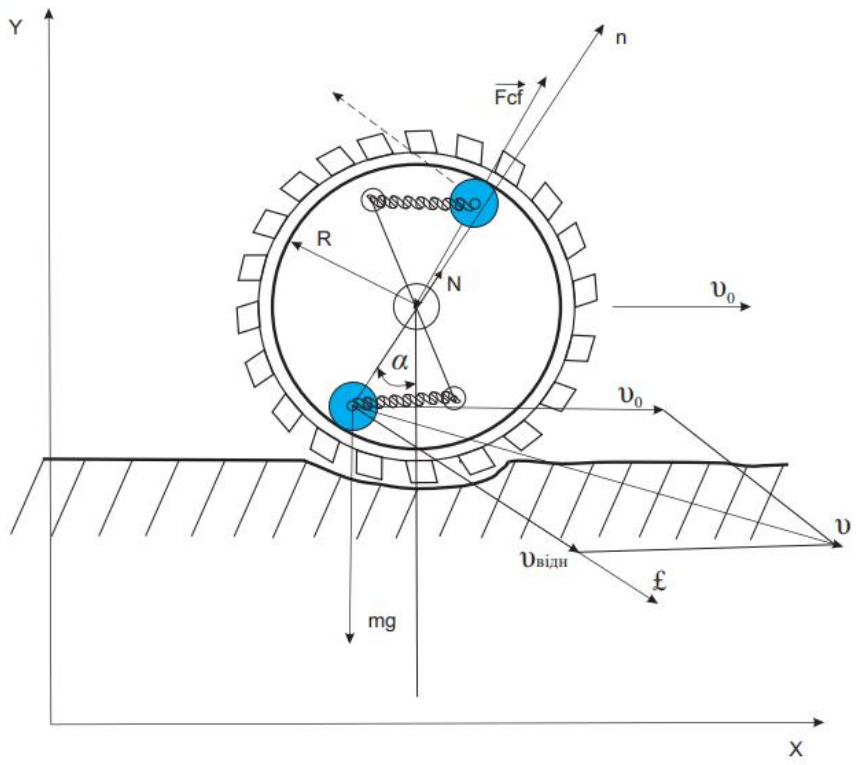

\section{Рис. 2. Фізична модель автомобільного колеса здодатковою рухливою вагою}

Для вирішення поставленої задачі використовуємо закон змінення механічної енергії і ваги за час, від початку їі руху від верхньої частини диска до нижньої тобто, коли вага буде в нижній точці диска.

Змінення механічної енергії рухомої ваги при ії русі від верхньої точки диску до нижньої точки диску буде представлено різницею потенційної та кінетичної енергії.

$$
\left(E_{b}^{n}+E_{b}^{k}\right)-\left(E_{h}^{n}+E_{h}^{k}\right)=A
$$

де $E_{b}^{n}-E_{1}^{n}=\mathrm{mgr}$ - змінення потенціальної енергії за розглядаємий інтервал часу. 


$$
E_{b}^{k}-E_{h}^{k}=\frac{m v^{2}}{2}-\frac{m v_{0}^{2}}{2}
$$

Зміна кінетичної енергії рухомої ваги за розглядаємий інтервал часу.

А- робота зовнішніх сил.

Зовнішньою силою згідно, рис.2 являється сила нормальної реакції, яка діє зі сторони диску автомобільного колеса на рухому вагу.

Робота цієї сили за невеликий проміжок часу $\Delta \mathrm{t}$ представлена формулою:

$$
\Delta \mathrm{A}=N * v \mathrm{dt}
$$

Для визначення сили $\mathrm{N}$ використовуємо природні осі системи координат, які зв'яжемо 3 автомобільним колесом. 3 цією метою запишемо рівняння руху ваги відносно природних осей системи координат в проекціях на нормальну $n$ та тангенціальну $\tau$ осі [3, с. 331-335]:

$$
\frac{m v^{2} \text { вid }}{R}=N-m g \cos \alpha
$$

Після диференціювання отримуємо

$$
\frac{m d v_{\text {BidH }}}{d t}=m q \sin \alpha
$$

le $m$ - маса рухливої ваги;

$v$ від $н$ модуль швидкості рухливої ваги відносно диску автомобільного колеса;

$\alpha$ кут між віссю $n$ та вертикальною віссю.

У наведеній системі відліку яку нами пов'язано 3 автомобільним колесом, рухлива вага рухається по колу радіуса $\mathrm{R}$, отже:

$$
\mathrm{v}_{\text {вiдн }}=-R \frac{d \alpha}{d t}
$$

Узагальнену швидкість руху рухливої ваги відносно природної системи відлікуосей координат буде:

$$
\mathrm{v}=\mathrm{v}_{\mathrm{o}}+\mathrm{v}_{\text {відн }}
$$

За допомогою попередніх рівнянь можна визначити кінематичні характеристики руху досліджуємої ваги.

Елементарна робота, яку виконує рухлива вага: 


$$
\delta A=m v_{\circ} \sqrt{\frac{g R \cos \alpha}{2}} \sin \alpha \cdot d \alpha
$$

Робота А, яку здійснює сила нормальної реакції опору в природній системі відліку та іінтервалі часу від початку руху до моменту попадання рухомої ваги в зону плями контакту автомобільного колеса з опорною поверхнею.

$$
\begin{gathered}
A=\int_{\frac{\pi}{2}}^{0} m v_{0} \sqrt{\frac{g R \cos \alpha}{2} \sin \alpha d \alpha} \\
A=m \sqrt{2 g R V_{0}}
\end{gathered}
$$

Отримана формула для роботи А рухливої ваги дозволяє отримати закон зміни механічної енергії автомобільного колеса:

$$
m g R+\frac{m v^{2}}{2}-\frac{m v_{0}^{2}}{2}=m \sqrt{2 g R V_{0}}
$$

Тоді шляхом рішення наведеного рівняння, відносно швидкості рухливої ваги в зоні плями контакту автомобільного колеса з опорною поверхнею, отримуємо формулу швидкості дляавтомобільного колеса:

$$
\mathrm{v}=V_{0}+\sqrt{2 g R}
$$

\section{Література:}

1. Петров Л. М. «Спосіб переміщення мобільного енергетичного засобу». 10.02.2015, Бюл. № 1.

2. Петров Л. М. «Спосіб переміщення мобільного засобу» 10.01.2014, Бюл. № 1.

3. Лобас Л.Г., Лобас Людм. Г. Теоретична механіка: Підручник для студентів вищих технічних навчальних закладів / Л.Г. Лобас, Людм. Г. Лобас. К.: ДЕТУТ, 2008. 406 с. С. 331-335. 